\title{
Celebrification of Politics: The Behavior Study of the Political Elite in West Sulawesi
}

\author{
Ahmad Al Yakin \\ Tahir Kasnawi \\ Sulaiman Samad
}

\begin{abstract}
Department of Sociology, Universitas Negeri Makassar, Jalan Bonto Langkasa Kampus Gunung Sari Baru, Makassar, South Sulawesi, Indonesia; Email: ahmadalyakin76@gmail.com, hirka_unhas@yahoo.com, essamad@yahoo.com
\end{abstract}

\section{Doi:10.5901/mjss.2016.v7n6p275}

\begin{abstract}
This study aims at exploring and analyzing the forms of celebrification conducted by the elite politicians in Polewali Mandar. This research was qualitative research with a constructivist approach. The political behavior of eight pairs of Regent candidates in Polman on the local election in 2013 was the object of study. The researchers acted as the main instrument because it was a qualitative research. The collected data include various types, forms, and model of political advertising used by the elite politicians when the election took place. The results showed that the political advertisements used by politicians are in the form of conventional media (billboards, banners, and calendars), online media (Facebook), VCD, Youtube, printed media, television media, and face to face model. Celebrity culture that emphasizes self-image seem to be very clear in the form of the tagline of politicians names so that it sounds cool. Also, those who have the image as a pious, intelligent, religious, and visionary people will be easily offered to the voting public. Another form is that the politicians act as a celebrity in the true sense.
\end{abstract}

Keywords: Elite Politicians-Behavior-Politics- Celebrification

\section{Introduction}

The approach in political socialization in practice has various forms that are intended to increase the popularity. One of them is to involve celebrities' attributes. In the international context, the celebrity approach as one of the socialization strategy in the political arena has been performed by Barack Obama during the election of the first period in which He used the media to help in winning the Presidential elections and exerted his status as a global celebrity, then a presidential candidate has made himself a celebrity (Kellner: 2009).

In line with the findings of Kellner, Garthwaite \& Moore (2012); Wheeler (2013) Drake and Higgins (Holmes \& Redmond: 2006); Pertierra (2012); Brokes \& Nolan (2012) analyze the role of celebrities in political campaigns. Therefore, celebrity endorsement in politics plays a major role in the political campaign.

The studies conducted by McLeod (2000); Buckingham (1997); Garramone and Atkin (1986); Hooghe (2004); Woodly (2008); Gooyong (2011) provide evidence that the mass media were the strongest predictors than political knowledge. The political system must find ways to adapt to society to be more critical.

Based on the various studies on celebrity in the political contest, it can be categorized into two tendencies namely politicians who are supported by a celebrity (celebrity endorsements), and celebrities who switched professions to become politicians. In a political context in West Sulawesi, involving celebrities' attributes seem different with the previous pattern. The maneuver of the elite politicians in West Sulawesi directly construct and portray themselves as celebrity through electronic media such as VCD, MP3, the internet, radio, local television, and printed media such as tabloid, billboards, and newspapers. Rojek (2001) conceived this maneuver as a celebrification of politics. He interprets celebrification as the process of presenting the character of celebrities in daily life. Furthermore, in Turner in Drissen (2013, p. 4) confirms celebrification as a process of transformation of ordinary people and public figures to became a celebrity.

Celebrification is a political strategy that is effective enough to gain a political vote. However, the selection of this strategy led to the silting of the political community. Society tends to impose his choice based on popularity alone. The more substance thing can be neglected. Vision, mission, work programs and the track record of the politicians are no longer the main political preferences. Polewali community has cultural capital that is strong enough in terms of choosing a leader. The main standard is the value, not the image. A person can be considered as a potential leader if he or she has a cultural value namely Lokko, siri, naratan, Naindo, dipattuangan, and chairperson. The core of this cultural chairperson 
is to be careful in choosing a leader because the leader is going to determine the direction of a region or nation. It is entirely different from the modern political culture that emphasizes individual image instead of the value.

Baudrillard theory can be used to explain how the image of celebrification is built through various political media as a strategy to become popular in the political arena. Baudrillard (1983) considered that the era of simulation and hyperreality is the part of the sequence of image phase. Baudrillard (Piliang, 2004) termed the media hyperreality in which is used to describe engineering (in terms of distortion) of meaning in the media. Scientific study on celebrification of politics is interesting to investigate because the researchers consider that this strategy has not been constructed properly. Therefore, the researchers proposed the following research questions. How are the process and the forms of celebrification conducted by the elite politician in West Sulawesi?

\section{Research Methods}

This research was qualitative research using constructivism approach through case studies selected in accordance with the main focus of this research which is to understand the processes and forms of celebrification performed by eight (8) pairs of candidates in the local elections in 2013 in Polewali Mandar.

The research location was in Polewali Mandar, West Sulawesi Indonesia.

The informants of research were selected by using purposive sampling. The informants are political actors who do celebrification in Polewali Mandar in 2013 including the successful team working to help the candidates. In order to obtain a holistic and integrative data to answer the research problem, primary data and secondary data were required. In collecting primary data, a field research methods consisting of interviews and observation were used. Meanwhile, the researchers applied documentation technique in collecting the secondary data.

The processes of collecting and analyzing data follow the flow of interactive cycle and takes place continuously so that the data become saturated. These stages include data reduction, display data, and Conclusions: drawing / verifying.

\section{Results and Discussion}

\subsection{The Form and the Process of Celebrification of Politician in Local Election}

Celebrification is the process of formation or establishment of a politician's image to the public through various types of media. The politicians are constructed as the object or subject of the advertisements. The politicians are mingled with the perspective of popular culture that emphasizes the image rather than ideology. The image is formed by the candidates who feel that its popularity is not so good. For example, Hikman Katohidar. He is a stranger in his village. Bureaucratic career, during which he passes, is located outside Polman (Gorontalo).

The image formation (by exploiting all his inherent potentials) should be made to attract the public in Polman. Establishment of the image is made by the candidates who actually have got a good name and a place in the public mind such as Andi Ibrahim Masdar, Najamuddin, Naharuddin, Asri Anas, Chudriah Sahabuddin. They are people who are already famous in Polman. Efforts that they do are to establish the image of the existing network and try to expand that image to have the broadest political support from the public.

The form of celebrification made by the regent candidates is relatively same. It is to play its image as the most appropriate person to lead Polewali Mandar. The image is a defender of the people, bearers of hope, the successor of development, and the most important image is the person who will carry Polman as developed and developing regions. This performing image is similar to the image conducted by the celebrities when they advertise themselves for certain commodities.

\subsection{Creating a New Name; Acronyms and Abbreviations}

The phenomenon of the use of nicknames or name tag occurs in the local election in 2013 in Polman. Some candidates modify their names to be used as a political trademark. Here is a list of nicknames of the regent candidate in Polman 1). Andi Ibrahim Masdar dan Muh. Natsir = AIM Benar; 2). Hikman Katorhidan-Najib Abdullah Majid= Hikman-NAAM; 3). Naharuddin- Abdi Manaf= Nahar-Mengabdi; 4). Munarfa Atjo-Bebas Manggazali = Mabes; 5). Mujjirin- Hasan Bado= Jihad; 6). Najamuddin Ibrahim-Erfan Kamil = Naib-Erfan.

Five of eight pairs of candidates use a new name as a symbol of their politics. The symbol is reduced from the elements name owned by a couple of candidates. There is also in the form of the acronym (AIM, NAAM), and abbreviations (Right, Headquarters, Jihad, Naib), part of the name (Hikman, Nahar). The use of the "new name" is used 
as a trademark. It is similar with the position of "brand name" in merchandise or "famous names" of an artist. The use of the name is sought to follow Indonesian syntagmatic so that the public easily digests it. Aim Benar, Hikman-Naam, Nahar Mengabdi, Jihad, and Mabes are acronyms and abbreviations that have the syntagmatic structure (rhythm language) in Indonesian. Semiotic sketches on "new name" indicate that the name is not presented simply as a collection of words, but it refers particular meaning. Phoneme of candidates name is constructed so as to establish a specific meaning.

In addition to a name tag, the candidates are also using a tagline that is typical of those in the campaign, namely: 1). Andi Ibrahim - M. Natsir: Pembangunan berkelanjutan (Sustainable development); 2). Najamuddin- Erfan Kamil: The next; 3). Hikman - Nadjib Abdullah: Peduli, amanah, dan pro-rakyat (Caring, trustworthy, and pro-people); Asri AnasChudriah Sahabudin: New Polman. The use of the tagline is a part of the frequency news marketing. The tagline is a popular mode of advertising. Each product uses not only the tagline for the brand but also the objectives or the foundation of a commodity being advertised.

\subsection{Political Advertising through Conventional Media (billboards, banners, cards, calendars)}

Local Election of Polman in 2013 is the election with the second direct election system. The first local direct election was in 2009. At that time, the candidate who won the competition was the incumbent candidate. He was Ali Baal Masdar. The use of media is very important in terms of socialization of prospective candidates. Media used in a direct election in 2009 is still conventional such as billboards, banners, cards, calendars. Whereas in 2013 , the media used has evolved. In addition to conventional media, the candidates (especially the successful team) used social media as an instrument of socialization.

Andi Ibrahim Masdar is a popular figure in Polewali Mandar. Masdar is a popular name in the public memory in Mandar in the last 15 years. He is one of the powerful political clan together Mengga, Majid, Lopa. Ali Baal Masdar is the elder brother of Andi Ibrahim Masdar, and he was a regent in two previous periods. In adition, Masdar (the father of Andi Ibrahim Masdar) is a former chairperson of the parliament in Polman. The popularity of Masdar as chairperson of the parliament and Ali Baal Masdar as regent for two periods provides an easy way for Andi Ibrahim Masdar as the regent candidate. Moreover, Andi Ibrahim Masdar itself has been featured as the regent candidate in 2009 against his brother. However, the popularity does not necessarily lead to the candidate to ignore the use of billboards and other socialization media.

Advertising (advertising) is derived from the Latin word advertere in the middle ages, "directing attention to". This term describes the type or public announcement for the promoted commodities to be sold (Marcel Danesi, 2004, p. 294). It is still important for a person who has been popular to use advertising media in addition to expanding the network of "consumers" or voters also to give a code to the (potential) voters that he was there. For this reason, candidates who already have good name such as Andi Ibrahim Masdar still need to put up a billboard in the protocol street in Polman to give a public announcement that he Polman forward is a candidate. Asri Anas who has been already a member of the DPD and Naharuddin who get significant votes in the 2009 election as a Member of Parliament of West Sulawesi province also had to put up billboards, banners, stickers as a political announcement especially for Katohidar Hikman who is a new participator in the political arena. He had introduced himself to the public through various types of advertisements.

The formal image is reinforced with peci. In the political culture of Indonesia, peci became a symbol of statehood and it is the national symbol. No other nation in the world makes peci as the symbol of official state clothing. In addition, the culture of Indonesian society also recognizes peci as a religious symbol of Islam. There are no Muslims in the world using a rectangular black cap (peci) as worship clothes except the Muslims of Indonesia (mostly Malaysian). Use of peci as the symbol in political advertising such as AIM Benar dan Hikman-NAAM represents these two things simultaneously with the pressure on the religious accent. Religious image wants to be emphasized more than national image. A religious image is important because most of the people in Polman are majority Muslim. Statistics show that $90 \%$ of people in Polman are an Islamic society. Religious meaning became one of the important icons in the structure of political advertising in Indonesia in general. Another meaning of suits, ties, and peci is the maturity and ripeness. The candidates are trying to explain to their constituents that they are ready and mature to become a leader in Polman.

The emergence of political advertising reinforces the assumption proposed by Baudrillard in which he called TV as an example. He stated that it is the heart of the postmodern culture that is characterized by the flow of simulations and facsimile that is satisfactory and covers all things. It is also a hyperreality in which we are bombarded with images and information.

It is the world where a series of modern distinction - the real with the unreal, the public and the private, art and reality-have collapsed or absorbed into a black hole. 


\subsection{Political Advertising through Social Media (Facebook)}

The influence of social media in the election of 2013 was not strong enough. It has led some candidates who ignore the use of social media as a media campaign. The reason is simple in which the public still limits the use Facebook applications in Polman, especially urban communities, and, youth. The "political market" in Polman is still many in rural areas which are not familiar with social media applications.

Although there is a pessimism about the use of social media among politicians, the trend of the use of social media, especially Facebook as a media campaign has begun implicated in the 2013 election. The candidate uses some of the Facebook group accounts in the form of open and closed. The enthusiasm of using Facebook media is not too high. The members or followers of each group were deserted, except for a group that has an account named Laskar $\mathrm{H}$. Andi Ibrahim Masdar. The group has many followers namely 888 members. The other group may not even reach tens of members. The most interesting are the readiness of the AIM team to use all the media path to winning. From 8 candidates, one candidate does not use the media Facebook. It is seen that Aim team is most widely used a Facebook account, and, the team has many followers. It indicates that although Facebook does not much influence the electability, the user can give a contribution to the victory of a regent candidate.

Facebook move the public space from the room of natural reality to the digital reality. The candidates through a successful team and loyalists use social media to strengthen the reality of building the image that they already do in the real world. What is interesting is the public space in the virtual world is more active and dynamic. All the activities that are incidental are uploaded and broadcasted to the public. The other interesting point is the emergence of critics. The virtual world makes the activities of "image formation" and "tearing down the image" are running simultaneously, even within the same account.

The future of the use of digital based social media will become increasingly important and increasingly used as an instrument massively considering that the use billboards and traditional media campaign have been limited by the General Election Commission (KPU) since the election was simultaneously performed in 2015. The limitation of the use of conventional campaign is intended to "regulate" the use of campaign funds. This policy can be, of course, open opportunities for media of campaigns to shift to the digital space. Facebook, twitter, youtube, WhatsApp, BBM messenger and other social media will be increasingly popular. They will, of course, be influenced by the revolution in the use of smartphones and Internet cafes which are starting to look implicated in Polewali and Wonomulyo.

\subsection{Celebrification through Mass Media}

The spectrum of the use of the mass media in Polman district is not an area of the state or provincial capitals. National television media cannot be used as a campaign tool because of limited range. It requires running costs which are enormous. In addition, there is a very broad scope. The target of the political market for regent candidates is only limited area (14 Sub-districts) in Polman district. Therefore, National TV broadcast is not needed. In addition, TVRI broadcast is felt less interest. It causes the television media is not the target of local politicians in Polman. The use of the national television media as an advertising media started to be used by couples of the candidate for Governor Anwar Adnan Aladin Saleh- S Mengga in West Sulawesi Province governor election in 2008. Meanwhile, Polman district level election, no candidate utilizes national television as a campaign media.

Electronic media that The cable is a cable television media. Since the 2000s, the development of the cable television media in Polman district has been going on rapidly. The cable television networks are utilized by the General Election Commissions to proclaim any information related to the election. This channel is also used by political actors to campaign themselves either in the form of static or motion advertisements.

Some successful teams recognize that they did make a special approach to the mass media to get news of their activities. It is very advantageous because it increases the sale value. Candidates who get frequency news market have many high points in the public eye. In the case of the local election in 2013 in Polman, Aim couples seem to be more prepared than the other candidates. At the time of the election took place, especially in the last three months, the news of Aim couple exist almost every day in the daily media Radar West Sulawesi.

The mass media is positioning itself as a pillar of neutral democracy. Anyone who wants to advertise is definitely loaded. They are not particularly taking into account the ideological basis of a candidate. The candidates who are willing to pay for the cost of advertising in the paper will be loaded. Exclusive advertisement depends on the amount of fees paid by a candidate. The presence of political advertising is a part of mutual symbolism between mass media and political actors. The actors need space to introduce themselves meanwhile mass media need advertisement to survive. li is known that the pulse of the mass media highly depends on paid advertising that they are marketed. 
Politicians realize advertising through mass media as a crucial part. It is not surprisingly that each candidate strives to appear as a public figure in the mass media (especially printed media). Even with these reasons, the candidate, Asri Anas-Chudriah Sahabuddin, pioneered the publication of internal printed media such as magazines containing all the news about the existence, expectations, strategies candidate's spouse.

\subsection{Political Advertising through Songs}

The use of the song as political advertising in Polman is divided into three types. The first is adapting songs that are popular in the country. The selected song is usually easy listening songs. Hikman-Naam couple uses this method to produce some songs composed by songs that are popular. Two songs are part of the album tracks produced by a team of Hikman-Naam. On the album, eight songs were entirely composed by popular songs like Mata hati (O Carol), Nafas Tim NA (lagu dangdut), Sayang Hikman Najib (Yank, Wali Band), Suka Cita Tim NAAM (Gulali Dunia, Rhoma Irama), Tanah Kelahiran (Lagu Dangdut). Two songs cited above entitled Hikman Oke is reproduced from songs "Sik Asi" belongs to Ayu Tinting (dangdut singer), and the song "Menunggu Pemilihan" composed by songs "menunggu", Rhoma Irama songs which have ever sung by Rita Sugiarto and popularized again by Ridho Rhoma. All the songs on the album were sung by a female artist. Menunggu song also seems to follow this logic election.

Second, original songs are created for the purpose of lifting or popularizing a politician. The song entitled Asri Anas for new Polman was uploaded on YouTube to strengthen the support for Asri Anas image. This song also inserts attacks against political opponents with words anreapi, do not choose it again and the word Tutar, do not select our leaders repeatedly. These lyrics were apparently intended to AIM (Andi Ibrahim Masdar). The issue of political clans (especially Masdar) was very strongly blowing in the General Election. Some candidates advertise the importance of breaking the chain of the political clan of Masdar that has ruled since the era of direct election. The presence of Andi Ibrahim Masdar as the clan of Masdar went on to become one of the "common enemies". The words "anreapi" and "tutar" are the reflection of the desire to break the clan leader of Masdar and replace it with a new leader in Polman, namely Asri Anas.

Third, the song was associated or not directly related to politics, but it was sung by a politician. For example, a song was sung by Chudriah Sahabuddin (prospective vice regent) which is entitled, Towaine Mandar in which the song tells the superiority of Mandar women. During the campaign, this song was imaged by Chudriah Sahabuddin as the only woman candidate (towaine) in the event of the local election in 2013. The song was produced in the same titled album with this song. There are ten songs which are all sung by Chudriah Sahabuddin, such as Lele Tammpasa'bi, Sukku elo'na, sipakatau, topriate (duet with Muhammad Bachtiar), and tidziassayangi. These songs are the nuanced songs of love and longing between men and women.

\subsection{Political Advertising via Face to Face}

Face to face method is a part of a political dramaturgy. The candidates are only "pretended" to do the sympathy so that they get the sympathy from the public. After the political process is completed, none of the candidates have come to the public again as they did during the campaign. The public is only a commodity to be managed in such a way to get votes. Even the elected regent is already very challenging to take the time to come face to face directly with the public the business in government bureaucracy. There is no political visit to markets and places of worship anymore as they did during the campaign.

Face to face, open campaign, and the dialogical campaign is a political space to connect the candidates' vision and expectation of the public. This space should be used by the public to establish a contract with each candidate. However, in fact, the campaign with face to face model is merely a formality. Everything has already arranged. What clothes will be used, what theme will be discussed, and where is the location have been set up in such a way by the candidates' team. The public who attended the campaign was certainly a supporter of the candidate or group of the public who mobilized to ensure that the public is enthusiastic about the arrival of the candidates.

Each candidate certainly comes up with the best smile and with the political promises that seemed to resolve the problem as a whole.

The image as the "famous people" is going to be immortalized on face-to-face, open campaign, and dialogical campaign. All the supporting instruments such as the descendants of a particular clan and achievements in the past were revealed in detail to the public to ensure that the candidates are required by Polman society to lead them for the next five years. 


\section{Conclusion}

Celebrification, as defined by Chris Rojek, is the adaptation of celebrity culture in the political context in which a politician acts like a celebrity. The politicians do the various ways to get the attention of the public in the form of popularity and electability. The forms of political celebrification that are most commonly performed by the politicians in the election of 2013 was performing through political advertising either in the form of billboards, banners, calendars, or cards. The used media consisted of printed media, cable television, Facebook, and on-line media. Celebrity culture that emphasizes selfimage appear very clearly in the form of political advertising offered by politicians. The tagline of politicians to sound cool, their image as a pious, intelligent, religious, visionary, and young are granted to the public as the voters. Reproduction of image repeatedly made the public want to turn his political preferences to the political advertisements. Candidates who do not have billboards or political advertising are considered as poor candidates, and they are not sold in the political market.

The politicians who act as a celebrity in the true sense are the other forms of celebrification. A politician who feels they have a good sound makes use of it to make an album of songs. The album is then distributed to the public. This action is conducted in shaping popularity among the voters. There are also politicians who adapted several popular songs by changing the words which can flatter themselves. This category actually is in the realm of celebrity endorsements, but the involvement of idiom of political candidates in the song shows the attempt of politicians to engage in celebrity culture.

\section{References}

Baudrillard, Jean. (1983). Simulation transl. Paul Foss, Paul Patton dan Phillip Beitchman, Semiotex(e).

Bodi, Muh. Idham Khalid. (2008). Local Wisdom: Benang Untaian Mutiara Hikmah Dari Mandar Sulawesi Barat. Nuqtah: Jakarta Timur. Brookes, Stephanie., and Nolan, David. (2013). Celebrity, Campaigns and Citizenship: 'Competing Populisms' $n$ the 2012 United States Presidential (Election presenting author asterisked) Australian Political Studies Association Annual Conference.

Buckingham, David. (1997). News media, political socialization and popular citizenship: Towards a new agenda . Critical Studies in Mass Communication. 14 (4), pp. 344-366.

Danesi, Marcel. (2012). Pesan, Tanda, dan Makna: Buku Teks Dasar Mengenai Semiotika dan Teori Komunikasi. Translated by Evi Satriani dan Luis Lian Piantari. Jalasutra: Yogyakarta.

Driessens, Olivier. (2013). The celebritization of society and culture: understanding the structural dynamics of celebrity culture. International Journal of Cultural Studies, 16 (6).

Garramone, Gina M. and Atkin, Charles K. (1986). Mass Communication and Political Socialization: Specifying the Effects. Public Opinion Q, 50 (1).

Garthwaite, Craig., and Moore, Timothy J. (2012), Can Celebrity Endorsements Affect Political Outcomes? Evidence from the 2008 US Democratic Presidential Primary. The Journal of Law, Economics, \& Organization, 29(2), pp. 355-383.

Gooyong, Kim . (2011). Online Videos, Everyday Pedagogy, and Female Political Agency: "Learning from YouTube" Revisited. Global Media Journal.

Habermas, Jurgen. (2007). Teori Tindakan Komunikatif I; Rasio dan rasionalisasi Masyarakat, Terjemah Nurhadi. Kreasi Wacana: Jogjakarta.

Holmes \& Redmond. (2006). Framing Celebrity New Directions in Celebrity Culture Routledge: Taylor \& Francis Group: London and New York.

Hooghe, Marc. (2004). Political Socialization and the Future of Politics. Journal Acta Politica.

Kellner, Dauglas. (2009). Barrack Obama and celebrity spectacle. Internasional journal of communication.

McLeod, Jack M. (2000). Media and civic socialization of youth. Journal of Adolescent Health.

Pertierra, Raul. (2012). The New Media, Society Politics in the Philippines. Fesmedia Asia: Berlin.

Piliang, Yasraf Amir. (2004). Posrealitas Realitas Kebudayaan dalam era Posmetafisika. Jalasutra: Bandung.

Rojek, C. (2001) Celebrity. Reaktion Books: London.

Spradley, James P. (1997). Metode Etnografi. Tiara Wacana Yogya: Yogyakarta.

Turner, Graeme. (2004). Understanding Celebrity. Sage: London.

Wheeler, Mark. (2013). Celebrity Politics: Image and Identity in Contemporary Political Communications, Polity Press, Amazon.

Woodly, Deva. (2008). New competencies in democratic communication? Blogs, agenda setting and political participation. Journal Public Choice. 